\title{
UKURAN TOKO DAN HOMOGENITAS BARANG DAGANGAN PENGARUHNYA TERHADAP DAYA TARIK TOKO TERHADAP KONSUMEN
}

\author{
Dipa Mulia \\ Program Pasca Sarjana Universitas Mercu Buana \\ Email:dipa.mulia@yahoo.com
}

\begin{abstract}
Introducing new store to customer usually create the "customer shift" from the existing store to the new one. When the new store is located nearby the existing one, the shifting could not be avoided; it means the efficiency of store is becoming less than before. In order to optimize the efficiency of store the distance between stores should be managed. This paper implements theClassic Model of Electrostatic Forces that also known as Model of Coulomb.The Model was promoted by France Physicist, Charles Augustine de Coulomb, in $18^{\text {th }}$ Century. The attractiveness of store to customer is represented by the electrostatic force on the Model. This paper is a descriptive research with a quantitative approach; the object of research is 5 (five) stores with different types in term of size and product offered. There were 60 qualified respondents selected on each store, in total it was 300 respondents. The result of the research tells that the size of store and the homogeneity of product offered are influencing the attractiveness ofthe store to the customer.
\end{abstract}

Key words: size of store, homogenity of product offered, store attractiveness, customers shift.

Abstrak: Munculnya toko toko baru biasanya menimbulkan "pergerakan konsumen" dari satu toko yang sudah ada kepada toko yang baru muncul. Toko toko yang letaknya saling berdekatan saling mempengaruhi satu sama lain dalam memperebutkan konsumen yang sama sehingga dapat dikatakan bahwa kinerja toko secara keseluruhan menjadi tidak efisisien. Model Elektrostatik atau Model Coulomb yang diperkenalkan oleh ahli Fiska abad 18, Charles Augustine de Coulomb dapat digunakan dalam menganalisis pengaruh toko terhadap konsumennya sehingga dapat dibuatkan desain toko agar kinerjanya menjadi efisien. Makalah ini dibuat melalui riset diskriptif dengan menggunakan pendekatan kuantitatif dengan mengambil sampel 5 buah toko dengan ukuran dan jenis yang berbeda. Responden diambil sebanyak 60 orang per toko dengan total responden sebanyak 300 orang. Hasil penelitian menunjukkan bahwa besar ukuran toko dan keragaman produk yang dijual mempengaruhi daya tarik toko terhadap konsumen.

Kata Kunci: Ukuran toko, keragaman produk, daya tarik toko, pergerakan konsumen

\section{PENDAHULUAN}

Sebuah toko (store/mart) yang menjajakan produk dalam bentuk barang (goods)berupaya menarikkonsumen atau menciptakan daya tarik terhadap konsumen sehingga konsumen bersedia datang ke toko tersebut untuk bertransaksi. Posisi toko yang terlalu berdekatan 
satu sama lain diperkirakan berakibat kurang baik karena akan terjadi perebutan pengaruh terhadap kelompok konsumen yang sama, sehingga terjadi pergeseran konsumen(customer shift) dari satu toko ke toko lainnya atau disebut juga terjadi "kanibalisme konsumen". Fenomena "kanibalisme konsumen" ini menjadi perhatian banyak pihak khususnyaketika sebuah "toko modern" dibangun di dekat area "warung tradisional", meskipun terdapat penelitian yang menyatakan bahwa secara ekonometrik tidak terdapat pengaruh langsungkehadiran "toko modern "terhadap "warung tradisional" (Adri:2008). Sebagaian besar masyarakat berpersepsi bahwa kehadiran toko modern dianggapsebagai penyebab matinya aktivitas warung tradisional yang ada disekitarnya yang disebabkan karena terjadi kanibalisme konsumen oleh "toko modern" terhadap "warung tradisional". Salah satu upaya yang dilakukan untuk menghindari "kanibalisme konsumen" adalah mengatur jarak antara toko modern dan warung tradisional. Hal serupa juga terjadi ketika supermarket (toko dengan ukuran yang lebih besar yang dikelola secara modern)hadir di suatu wilayah yang dinilai sebagai penyebab terjadinya pergeseran konsumen toko dan warung disekitarnya bahkan juga konsumen supermarket lain yang telah lebih dahulu ada di wilayah tersebut, dengan kata lain kinerja toko-toko secara agregat (keseluruhan) menjadi tidak efisien.Pengaturan jarak antar toko, baik dalam bentuk warung, toko modern,supermarket ataupun hypermarket dalam suatu wilayah perlu dilakukan agar kinerja toko menjadi lebih efisen.Salah satu model yang dapat dipakai untuk memperkirakan jarak efisien antar toko, warung ataupun supermarket adalah model fisika yang biasanya dipakai untuk menjelaskan daya tarik menarik antar dua muatan listik dalam Hukum Coulomb.

Identifikasi Masalah. Seperti yang disampaikan dalam bagian latar belakang bahwa terjadi fenomena "kanibalisme konsumen" atau "customer shift" yang disebabkan oleh daya tarik toko yang berdekatan terhadap konsumen yang sama. Perlu dilakukan pengendalaiandaya tarik toko terhadap konsumen untuk menciptakan kinerja toko yang lebih effisien.Kehadiran toko modern (minimarket) telah mempengaruhi secara signifikan pendapatan toko tradisional (Dwinita:2011)

Penelitian ini bertujuan ini adalah untuk mengimplementasikan "Model Coulomb" dalam menetapkan faktor yang mempengaruhi daya tarik toko (store) terhadap konsumen, dengan demikian dapat ditetapkan jarak effisien antar toko agar "kanibalisme konsumen" atau " customer shift" dapat diminimalisir.

\section{KAJAIN TEORI}

Model Coulomb. Mempelajari daya tarik menarik antara muatan listrik dalam bidang fisika yang diformulasikan dalam Hukum Coulomb memberikan inspirasi bahwa hal yang serupa dapat pula terjadi dalam bisnis, khususnya dalam ilmu marketing, yaitu tarik menarik antara konsumen dengan toko sebagai penyedia barang(goods).Hukum Coulomb diperkenalkan pada abad 18 oleh fisikawan Perancis bernama Charles Augustin de Coulomb yang menyatakan bahwa:

Besarnya daya tarik dua muatan listrik $\left(\mathrm{Q}_{1}\right.$ dan $\left.\mathrm{Q}_{2}\right)$ besarnya berbanding lurus dengan besar muatan listrik masing masing dan berbanding terbalik dengan kuadrat jarak $\left(\mathrm{r}^{2}\right)$ antara dua muatan listrik tersebut. (Griffith :1998)

Secara matematis dapat dituliskan sebagai $\quad F_{12}=\left(Q_{1} \times Q_{2}\right) / r^{2}$ 
dimana: $F_{12}$ adalah besarnya daya tarik muatan listrik 1 terhadap 2; $\mathrm{Q}_{1}$ adalah besarnya muatan listrik 1; $\mathrm{Q}_{2}$ adalah besaranya muatan listrik 2; $\mathrm{r}$ adalah jarak antara muatan listrik 1 dengan muatan listrik 2 .

Dalam kaitannya dengan daya tarik toko terhadap konsumen maka analogi yang dapat dipakai adalah: $\mathrm{F}_{\mathrm{TK}}=(\mathrm{T} \times \mathrm{K}) / \mathrm{r}^{2}$

Dimana: FTK = daya tarik toko terhadap konsumen; $\mathrm{T}=$ besarnya ukuran toko; $\mathrm{K}=$ besar daya beli konsumen; $r=$ jarak antara toko dan konsumen.

Selanjutnya untuk mempermudah pembahasan pengaruhtoko terhadap konsumen, maka daya beli konsumen (K) dianggap selalu tetap atau tidak terdapat perubahan daya beli konsumen terhadap setiap produk barang (goods) di setiap toko.Jika ukuran toko adalah 1 satuan $(\mathrm{T})$, pendapatan konsumen adalah 1 satuan $(\mathrm{K})$ dan jarak antara konsumen (r) adalah 1 satuan jarak, maka daya tarik toko terhadap konsumen (FTK) pada lintasan lingkaran dalam gambar di atas adalah 1 satuan (garis ini merupakan batas kritis efektifitas daya tarik Toko terhadap konsumen $\mathrm{K}$ dengan FTK $=1$ dengan $\mathrm{r}$ sebagai jarak atau rentang efektifitas kritis daya tarik toko). Jika konsumen berada di area luar lingkaran atau jarak antara toko dan konsumen lebih besar dari 1 satuan jarak (r), maka daya tarik toko terhadap konsumen menjadi mengecil $(<1$, atau efektifitas daya tarik Toko terhdap konsumen (K) berkurang) sedangkan apabila posisi konsumen berjarak kurang dari 1 satuan jarak (r) atau posisinya berada pada lingkaran bagian dalam, maka daya tarik toko terhadap konsumen membesar (>1, atau efektifitas daya tarik toko terhadap konsumen $(\mathrm{K})$ bertambah). Semakin dekat konsumen terhadap toko semakin besar daya tarik toko terhadap konsumen dan begitu pula sebaliknya, semakin jauh jarak antara konsumen dan toko, maka semakin kecil daya tarik toko terhadap konsumen (lihat gambar 1)

Jika ukuran toko membesar menjadi empat kali lipat dari semula (4T), maka pengaruh daya tarik menjadi empat kali lebih kuat (4xFтк) dengan besar FTKsebesar 1 satuan terletak pada lingkaran dengan jari jari 2 r, dengan kata lain dapat dikatakan bahwa dengan membesarnya ukuran Toko menjadi 4 kali lebih besar maka radius (rentang) efektifitas kritis daya tarik Toko terhadap konsumen meningkat 2 kali lebih besar. Sebagai konsekuensi perubahan ukuran Toko maka untuk konsumen yang sama $(\mathrm{K})$ yang berada diposisi < 2r akan mendapatkan daya tarik FTK> 1, artinya daya tarik toko dengan ukuran 4T memiliki daya tarik yang lebih besar dari toko yang berukuran $\mathrm{T}$ dengan kata lain semakin besar ukuran toko, maka semakin besar pula rentang (jarak) efektifitas kritis daya tariknya terhadap konsumen.

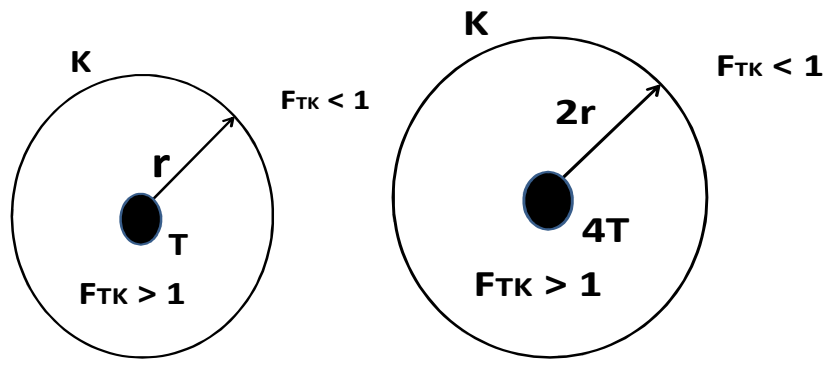

Gambar 1. Pengaruh ukuran toko (T) bagi daya tarik terhadap Konsumen (K)

Seandainya terdapat 2 (dua) pengaruh daya tarik toko terhadap konsumen (gambar 2), maka secara teoritis konsumen akan cenderung menuju ke toko yang memberikan daya tarik yang lebih besar. Kecenderungan pergerakan konsumen akibat perbedaan daya tarik 
toko tersebut dapat tergambar sebagai berikut. Jika toko A besarnya sama dengan toko B, maka untuk konsumen yang sama $(\mathrm{K})$ yang terletak di posisi $\mathrm{X}$ akan cenderung tertarik ke toko A karena daya tarik toko A lebih besar dari toko B terhadap konsumen di posisi X. Sedangkan jika konsumen berada di posisi Y, maka konsumen cenderung tertarik ke toko B karena daya tarik toko B lebih besar dari toko A bagi konsumen di posisi Y.

Model Hukum Coulomb yang dibahas di atas mengacu kepada asumsi bahwa daya tarik toko terhadap konsumen terjadi oleh satu toko sebagai satu kesatuan dengan karakter sejenis yaitu toko yang menjual berbagai jenis (variasi) produk di dalamnya sehingga faktor yang membedakan warung, toko dan supermarket adalah hanya faktor ukuran.

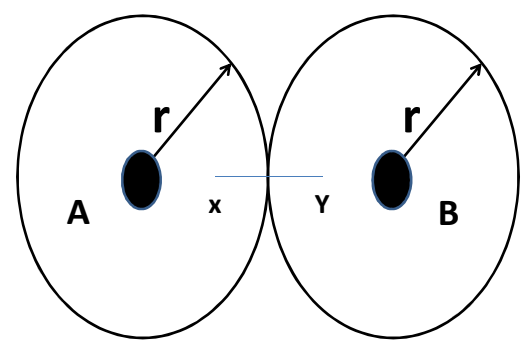

Gambar 2. Pengaruh 2 toko terhadap konsumen

Pengembangan dari Hukum Coulomb adalah bahwa muatan listrik dapat berkumpul menjadi suatu kumpulan tertentu dan secara agregat akan memberikan daya tarik kepada muatan listrik lainnya. Kumpulan muatan listrik dalam membentuk gugus dapat tersusun searah ataupun tidak secara acak.Pada gambar 3(a) di bawah ini menunjukkan bahwa Q1 merupakan gugus muatan listrik yang dibentuk oleh kumpulan muatan listrik dengan arah yang acak yang kemudian secara agregat (bersama sama) memberikan daya tarik sebesar F12 kepada $\mathrm{Q}_{2}$ yang berjarak r. Sedangkan gambar 3(b) menunjukkan Q3 yang merupakan gugus muatan listrik yang dibentuk oleh kumpulan muatan listrik yang memiliki keselarasan arah dan secara bersama sama memberikan daya tarik kepada $Q_{2}$ yang berjarak $r$ sebesar $F_{32}$. Berdasarkan teori fiska ini, maka $F_{12}<F_{32}$, artinya keseragaman arah muatan listrik dalam membentuk gugus muatan listrik memberikan daya tarik yang lebih besar terhadap Q2 dibandingkan dengan daya tarik gugus muatan listrik yang terbentuk secara acak.Analogi dalam ilmu marketing adalah bahwa gugus muatan listrik sebagai analogi dari sebuah toko (T) sedangkan muatan listrik yang ada di dalamnya sebagai produk barang (goods) yang ada di dalam toko.Keseragaman arah sebagai analogi homogenitas produk (barang dagangan) yang terdapat di dalam toko. Ukuran toko yang sama akan memberikan daya tarik yang lebih besar jika produk (barang dagangan) yang ada di dalamnya relatif lebih homogen.

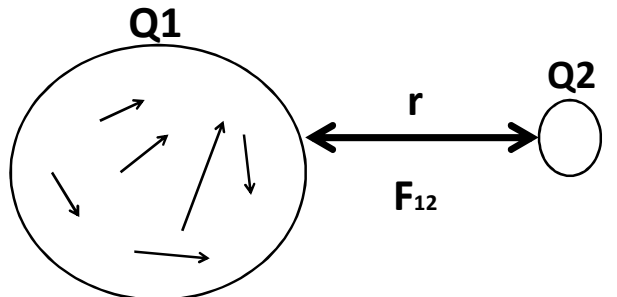

F32> F12

Gambar 3(a)

Gugus dengan arah muatan acak

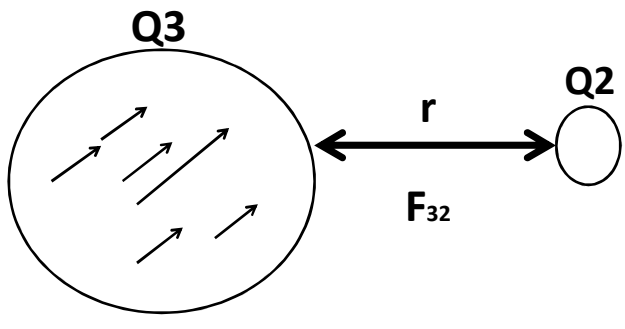

Gambar 3(b)

Gugus dengan arah muatan seragam 
Pasar Ritel (Retail). Pasar ritel (retail) adalah pasar yang mana produsen melakukan upaya agar dapat melayani langsung kepada konsumen akhir atau end user. (Gilbert, 2003). Bisnis ritel adalah institusi bisnis yang paling tidak 50\% pendapatannya diperoleh dari pengguna akhir yang motif belanjanya adalah untuk keperluar pribadi atau keluarganya. (Asep, 2005). Pasar ritel dapat berupa barang ataupun jasa dan di Indonesia pasar ritel terbuka bagi semua pengusaha baik pengusaha domestik maupun pengusaha asing, hal ini tertera dalam Keputusan Presiden (Keppres) No. 96 tahun 2000 yang mengatur tentang dicabutnya pelarangan investasi asing (Penanaman Modal Asing) di sektor ritel (Ahmad, 2008).Pasar ritel pada dalam bentuk barang (goods) pada dasarnya tidak terbatas pada barang (goods) tertentu akan tetapi semua jenis barang tanpa memperhatikan harga ataupun jenisnya, seperti: mobil, rumah, peralatan tulis, peralatan rumah tangga, dll, akan tetapi dalam tulisan ini pasar ritel dibatasi pada produk produk sehari hari atau "consumer goods" .

Usaha ritel untuk consumer goodsdi Indonesia pada saat ini dilakukan dalam tempat berupa toko (store) yang ukurannya berbeda beda mulai dari toko kecil tadisional, toko sedang (mart/supermarket) bahkan toko besar (hypermarket). Peraturan Presiden No. 112 Tahun 2007 pada pasal 3 ayat 2 membagi jenis toko modern berdasarkan ukurannya, yaitu toko modern dengan ukuran luas lantai kurang dari $400 \mathrm{~m}^{2}$ disebut sebagai mini market, sedangkan ukuran $400 \mathrm{~m}^{2}-5000 \mathrm{~m}^{2}$ disebut dengan supermarket dan toko dengan luas lantai di atas $5000 \mathrm{~m}^{2}$ dikenal sebagai hypermarket. Sedangkan toko tradisional adalah toko yang dikelola pemerintah atau bekerjasama dengan swasta yang diperuntukan bagi pengusaha dengan modal kecil (tanpa memperjelas ukuran toko). Ukuran toko ini diperkirakan penulis akan mempengaruhi konsumen dalam berbelanja.

Beberapa peneliti mengelompokkan pasar ritel kedalam 2 kelompok besar yaitu pasar (toko) tradisional dan pasar (toko) modern. Kedua kelompok ini dibedakan atas beberapa karakteristik tertentu seperti: Kualitas Produk, Harga Produk, Kualitas Pelayanan, Lokasi, Variasi Produk yang ditawarkan (Rina:2008). Penulis mengamati bahwa penilaian terhadap karakteristik tersebut toko tradisional secara umum lebih inferior dibandingkan dengan toko modern ditinjau dari perspektif konsumen. Inferioritas tersebut dapat ditunjukkan dengan persepsi konsumen bahwa kualitas produk toko tradisional lebih rendah dari toko modern, pelayanan toko tradisional lebih buruk, toko tradisional tidak teratur (tidak well managed).

Menurut beberapa peneliti, daya tarik toko terhadap konsumen dapat ditentukan pula oleh faktor tertentu seperti: cita rasa, fanatisme konsumen, harga (Salvatore, 2006) sedangkan pendapat lain (Teller, 2008) menyatakan bahwa daya tarik dapat dipengaruhi oleh faktor berikut: (1) Lokasi: aksesibilitas, jarak dan fasilitas dilokasitersebut; (2) Produk: jenis barang yang dijual sesuai dengan kebutuhan konsumen; (3) Lingkungan: keamanan dan kenyamanan. Pengamat lain menyatakan bahwa faktor yang mempengaruhi konsumen dalam memilih toko antara lain adalah lokasi, teknologi, harga, kualitas produk (Euis:2008)

Daya tarik toko (store/mart) dapat dipengaruhi pula oleh tata letak (layout) toko dan kualitas pelayanan yang diberikan kepada pelayan (Nel, 2013). Hal lain yang mempengaruhi pilihan konsumen untuk memilih toko modern atau tradisional adalah kondisi sosial-ekonomi, budaya dan etnik (Goldman, 2005)

Begitu banyak parameter yang dapat menciptakan daya tarik toko terhadap konsumen dan tidak terlepas pula dari karakteristik toko (toko modern dan tradisional), akan tetapi penelitian ini lebih menitik beratkan kepada dua variable yaitu ukuran toko dan 
keragaman produk yang ditawarkan sehingga dan tidak terpaku kepada pembagian kelompok besar toko yaitu toko tradisional dan toko modern. Untuk keperluan penelitian ini maka dibuat asumsi asumsi sebagai berikut: (1) Konsumen adalah realistis sehingga tidak menyertakan aspek pskologis seperti fanatisme, cita rasa, dan lain-lain; (2) Harga dan kebutuhan produk diasumsikan sesuai dengan preferensi konsumen; (3) Sebagian besar produk yang dijual dapat diperbandingkan antar toko; (4) Aksesibilitas, fasilitas, pelayanan dan kenyamanan serta keamananan diasumsikan sama untuk semua toko; (5) Teknologi yang dimiliki toko yang diteliti diasumsikan memenuhi kebutuhan konsumen

\section{METODE}

Penelitian ini berupa penelitian deskriptif eksporatif melalui pendekatan kuantitatif dengan menerapkan model "Hukum Coulomb" ke dalam aktivitas marketing khususnya yang berkaitan dengan daya tarik toko (store/mart) terhadap konsumen. Beberapa parameter dasar yang dijadikan bahasan dalam penelitian ini adalah jarak antara toko dengan konsumen, ukuran toko dan keragaman produk yang ditawarkan di dalam toko.

Objek Penelitian. Pengamatan dilakukan di kota A dengan mengambil titik pengamatan di 3 buah Toko dengan karakteristik serupa yaitu memiliki variasi produk barang (goods) yang tidak homogen yang masing masing berukuran lebih kurang (80 - 300) meter persegi (kategori kecil /mart), (800 - 1200) meter persegi (kategori sedang / super market), sebuah toko dengan luas area (lebih dari 1500) meter persegi (kategori besar / hypermarket). Selain tiga toko tersebut diambil pula titik pengamatan di dua buah toko dengan karakteristik produk yang homogen (yaitu 1 buah toko kue dan 1 buah toko buah \& sayuran) yang berukuran relatif sama yaitu lebih kurang $(80$ - 300) meter persegi (kategori kecil). Mengacu kepada kriteria Peraturan Presiden no. 112 tahun 2007 maka semua toko yang dijadikan objek penelitian adalah masuk ke dalam katagori toko modern.

Pengumpulan Data. Pada tiap-tiap titik pengamatan (toko) diambil sampel sebanyak 60 sampel yang diperoleh dari pengunjung toko - toko tersebut, untuk menghindari faktor seasonal (pengaruh waktu tertentu terhadap karakter responden), maka sampel diambil sebanyak 30responden pada saat weekdays (rentang senin - jum'at) dan 30 responden saat weekend (rentang Sabtu - Minggu).

Asumsi asumsi yang dipakai dalam penelitian ini adalah: (1) Konsumen memiliki daya beli yang relatif sama atas produk barang (goods) yang dipasarkan di took; (2) Setiap toko diasumsikan memiliki aksesibilitas yang sama, artinya setiap konsumen di setiap toko mempunyai kemudahan akses untuk mencapai toko dan memiliki kemampuan untuk membeli produk yang ada di took; (3) Konsumen adalah pengunjung toko yang menyengajakan diri datang ke toko tersebut, bukan karena kebetulan (sambilan). Hal ini dapat dilakukan penyaringan dengan menggunakan kuesioner yang disampaikan dalam penelitian.

Desain Kuesioner. Pertanyaan dalam kuesioner cukup sederhana karenapertanyaan tersebut disesuaikan dengan kebutuhan penelitian, kuesioner disampaikan secara lisan yang kemudian dicatatkan oleh peneliti sehingga konsumen tidak disibukan dengan urusan membaca dan mengisi kuesioner (metoda ini seperti wawancara singkat). 
Pertanyaan singkat yang diajukan adalah: (1) Apakah bapak/ibu datang ke toko ini secara sengaja dari rumah (tempat kediaman) atau karena kebetulan lewat ?; (2) Dimanakah letak (area) domisili bapak / ibu ?

Pertanyatanyaan no.2 ini dimaksudkan untuk mendapatkan data mengenai jarak antara konsumen dengan toko atau dalam teori dinotasikan dengan (r),pengukuran jarak dapat dilakukan dengan menggunakan peta biasa yang berskala (conventional map) ataupun dengan peta elektronik (sepeti: google map ataupun yang lainnya). Pertanyaan no. 1 dipakai untuk melakukan penyaringan (filtering) terhadap konsumen yang secara tidak sengaja datang ke toko, karena konsumen yang mampir secara tidak sengaja memberikan data yang kurang baik (bias)terhadap jarak antara konsumen dengan toko.Pemilihan sampel dalam metoda ini tidak memberikan kesempatan yang sama bagi semua konsumen yang mengunjungi tokoatau non probably sampling(Sekaran : 2010) jika responden tidak memenuhi kriteria dalam pertanyaan no. 1, maka pertanyaan no. 2 tidak ditanyakan lebih lanjut kepada responden dan responden tidak dimasukan ke dalam sampel penelitian.

Hypothesis . Terdapat 2 buah Null Hypothesis (Ho) dalam penelitian ini yaitu:

Ho (1) = Perbedaan ukuran Toko tidak mempengaruhi daya tarik Toko terhadap konsumen

Ho (2) = Keragaman produk dalam Toko tidak mempengaruhi daya tarik Toko terhadap konsumen

Data dan Analisis Data. Data jarak antara toko dan konsumen (r) yang diperoleh dari 5 toko (titik pengamatan) di atas kemudian dipetakan dan diberikan score berdasarkan kriteriajarak tertentu kemudian disampaikan tabulasi distribusi (sebaran) jarak untuk tiap titik pengamatan(lihat gambar zoning di bawah). Kriteria yang dipakai dalam menetapkan score adalah rentang (range)jarak antara Toko dan konsumen (r) sebagai berikut:

Untuk jarak (r), dimana: $\mathrm{r}<300$ meter $=1 ; 300<\mathrm{r}<600$ meter $=2 ; 600<\mathrm{r}<900$ meter $=3 ; 900<\mathrm{r}<1200$ meter $=4 ; 1200<\mathrm{r}<1500$ meter $=5 ; 1500<\mathrm{r}<1800$ meter $=6 ; 1800<\mathrm{r}<2100$ meter atau lebih $=7$.

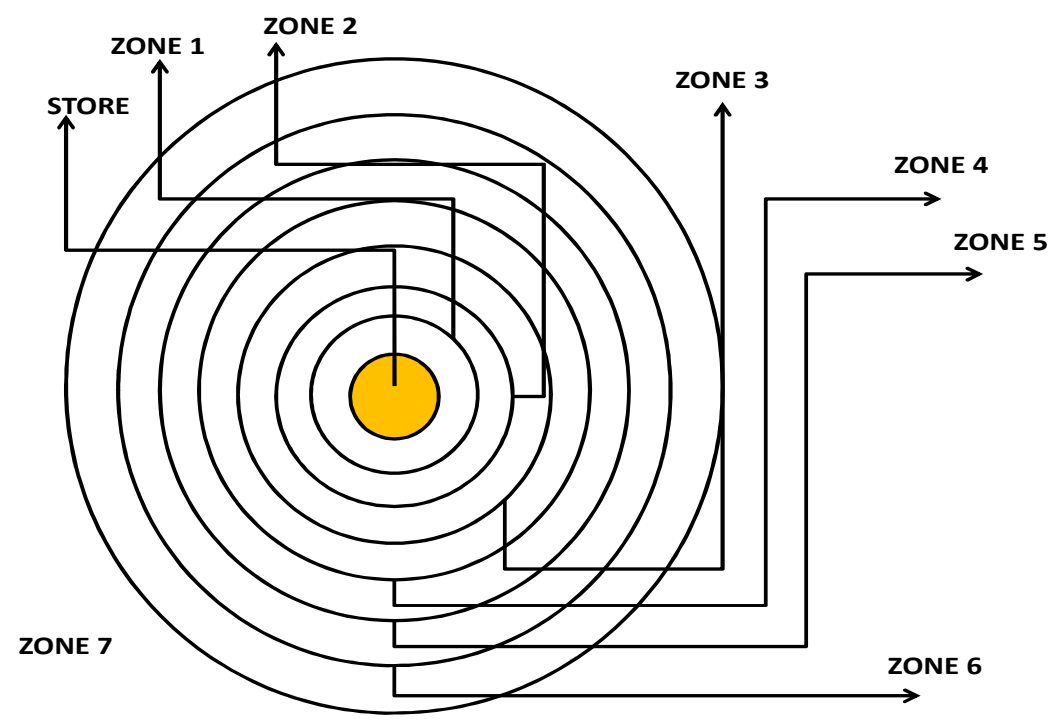

Gambar 4. "Zoning" Peta Radius Jarak antara Toko (store) dengan Konsumen 
Tabulasi data hasil pengamatan dari 60 sampel untuk masing masing toko / titik pengamatan (5 titik pengamatan), yaitu Toko-1 (kategori kecil), Toko-2 (kategori sedang), Toko-3 (kategori besar), Toko-4 (Toko Kue dengan kategori kecil), Toko-5 (Toko Buahdengan kategori kecil).

Hasil pengamatan pada Tabel 1 dapat dibaca sebagai berikut, misalnya Toko-1 (kategori kecil), pengamatan yang dilakukan pada saat weekdays, dari 30 pengunjung yang terpilih menjadi responden diperoleh sebaran sebagai berikut: (1) Sebanyak 8 konsumen berasal dari tempat (domisili) yang berjarak kurang dari 300 meter dari Toko 1 (score 1); (2) Sebanyak 9 konsumen terpilih berasal dari domisili yang berjarak 300 - 600 meter dari Toko 1 (score 2); (3) Sebanyak 7 konsumen terpilih berasal dari domisili yang berjarak 600 - 900 meter dari Toko (score 3); (4) Sebanyak 3 konsumen dengan score 4; (5) Sebanyak 1 konsumen untuk score 5; (6) Sebanyak 2 konsumen untuk score 6; (7) 0 (nol) artinya tidak ada konsumen yang terpilih yang berasal dari domisili yang berjarak 1800 - 2100meter atau lebih (score 7).

Metoda ataupun cara pembacaan yang samaseperti di atas dapat diterapkan baik pada toko lainnya maupun pada data pengamatan pada saat weekend.

Tabel 1. Pengamatan pada saat Weekdays (Senin - Jum'at)

\begin{tabular}{rrrrrrrrrrrr}
\hline Score & Toko 1 & Accum & Toko 2 & Accum & Toko 3 & Accum & Toko 4 & Accum & Toko 5 & Accum \\
\hline 1 & 8 & 8 & 5 & 5 & 5 & 5 & 4 & 4 & 4 & 4 \\
2 & 9 & 17 & 5 & 10 & 2 & 7 & 3 & 7 & 6 & 10 \\
3 & 7 & 24 & 8 & 18 & 3 & 10 & 4 & 11 & 5 & 15 \\
4 & 3 & 27 & 6 & 24 & 4 & 14 & 7 & 18 & 7 & 22 \\
5 & 1 & 28 & 5 & 29 & 5 & 19 & 8 & 26 & 5 & 27 \\
6 & 2 & 30 & 1 & 30 & 7 & 26 & 2 & 28 & 2 & 29 \\
7 & 0 & 30 & 0 & 30 & 4 & 30 & 2 & 30 & 1 & 30 \\
\hline \multicolumn{1}{l}{ Total } & $\mathbf{3 0}$ & & $\mathbf{3 0}$ & & $\mathbf{3 0}$ & & $\mathbf{3 0}$ & & $\mathbf{3 0}$ &
\end{tabular}

Tabel 2. Pengamatan pada saat Weekend (Sabtu - Minggu)

\begin{tabular}{rrrrrrrrrrrr}
\hline Score & Toko 1 & Accum & \multicolumn{1}{l}{ Toko 2 } & Accum & Toko 3 & Accum & Toko 4 & Accum & Toko 5 & Accum \\
\hline 1 & 7 & 7 & 4 & 4 & 4 & 4 & 3 & 3 & 3 & 3 \\
2 & 8 & 15 & 7 & 11 & 3 & 7 & 5 & 8 & 6 & 9 \\
3 & 9 & 24 & 9 & 20 & 2 & 9 & 4 & 12 & 3 & 12 \\
4 & 1 & 25 & 3 & 23 & 4 & 13 & 7 & 19 & 8 & 20 \\
5 & 3 & 28 & 4 & 27 & 7 & 20 & 6 & 25 & 5 & 25 \\
6 & 2 & 30 & 2 & 29 & 5 & 25 & 3 & 28 & 3 & 28 \\
7 & 0 & 30 & 1 & 30 & 5 & 30 & 2 & 30 & 2 & 30 \\
\hline Total & $\mathbf{3 0}$ & & $\mathbf{3 0}$ & & $\mathbf{3 0}$ & & $\mathbf{3 0}$ & & $\mathbf{3 0}$ & \\
\hline
\end{tabular}

Uji keabsahan data di atas (Rahmat, 2013) perlu dilakukan dengan menguji beberapa aspek, mengingat penelitian di atas menggunakan pendekatan kuantitatif, maka uji absahan untuk tiap aspek adalah: (1) Nilai Kebenaran data (credibility), dengan menerapkan pengamatan dalam season yang berbeda (weekend dan weekdays); (2) Aspek Penerapan (Transferability), metoda yang digunakan relatif mudah dan sederhana sehingga dapat dilakukan penelitian sejenis oleh peneliti lain; (3) Aspek Konsistensi (Dependability), penelitian ini sangat sederhana sehingga mudah untuk dilakukan audit terhadap tahapan tahapan penelitiannya dan relatif mudah untuk dilakukan audit atas konsistensinya; (4) Aspek Netralitas (Confirmability), penelitian ini dapat diulang-ulang dengan mudah sehingga dapat dengan mudah pula dinilai aspek netralitasnya. 
Analisis Pengaruh Ukuran Toko Terhadap Daya Tarik . Berdasarkan 60 sampel data yang diambil dari Toko 1 (kategori kecil)diperoleh hasil bahwa rata rata jarak yang antara konsumen dan Toko 1 adalah 785 meter dengan standard deviasi sebesar 435 meter, jarak rata rata pada Toko 2 (kategori sedang) adalah 950 meter dengan standard deviasi 453 meter, sedangkan untuk Toko 3 (kategori besar) adalah 1.305 meter dengan standard deviasi sebesar 605 meter. Rata rata jarak antara toko dan konsumen membesar ketika ukuran toko membesar, artinya semakin besar ukuran toko, maka semakin jauh pula rentang daya tarik efektifnya terhadap konsumen. (lihat tabel di bawah ini)

Tabel 3. Perbandingan Jarak Rata-rata Toko dan Konsumen (1)

\begin{tabular}{lrrr} 
& Toko 1 & \multicolumn{1}{c}{ Toko 2 } & \multicolumn{1}{c}{ Toko 3 } \\
\hline AVERAGE & 785 & 950 & 1305 \\
STDV & 435 & 453 & 605 \\
\hline
\end{tabular}

Uji hipothesis. Ho (1): Tidak terdapat perbedaan yang signifikan atas daya tarik toko terhadap konsumen karena perbedaan ukuran toko

Hipothesis di atas dapat diartikan bahwa tidak ada perbedaan yang signifikan untukrata rata daya tarik toko terhadap konsumen antara ukuran Toko 1 (kategori kecil)dan ukuran Toko 2 (kategori sedang) demikian pulan antara Toko 1 (kategori kecil) danToko 3 (kategori sedang) serta Toko 2 dan Toko 3. Jumlah sampel per titik pengamatan yang berjumlah 60 sampel dapat dikatakan relatif kecil (sedikit) < 300 sampel, sehingga digunakan perhitungan distribusi $\mathrm{t}$ ( $\mathrm{t}$ value) (Lukas : 2009). Hasil perhitungan $\mathrm{t}$ value untuk pengujian hypothesis mengenai rata rata jarak efisisen dari 2 Toko yang berbeda tergambar seperti tabel berikut

Tabel 4. Perhitungan t value (1)

\begin{tabular}{cccc}
$\mathrm{t}$ value & Toko 1 & Toko 2 & Toko 3 \\
\hline Toko 1 & 0.0 & -2.0 & -5.4 \\
Toko 2 & 2.0 & 0.0 & -2.3 \\
Toko 3 & 5.4 & 2.3 & 0.0 \\
\hline
\end{tabular}

Untuk $\alpha=5 \%$, maka tingkat penerimaan Ho dalam tabel adalah $-1,96<\mathrm{t}<1,96$, karena nilai $\mathrm{t}$ hitung antar Toko tidak berada dalam rentang (range) tersebut maka Ho ditolak, berarti terdapat perbedaan signifikan rata rata daya tarik toko terhadap konsumen karena perbedaan ukuran toko. Kesimpulan dari analisis ini adalah bahwa semakin besar ukuran toko maka semakin radius (jarak) pengaruhnya dalam menarik konsumen untuk ingin datang ke toko tersebut.

Analisis Pengaruh Keragaman Produk Terhadap Daya Tarik Toko. Toko-1, Toko-4 dan Toko-5 semuanya merupakan toko yang masuk ke dalam kategori kecil, perbedaannya adalah Toko-1 menjajakan produk yang beragam sedangkan Toko-4 dan Toko-5 menjajakan produk yang relatif seragam (homogen). Hasil pengamatan jarak rata rata untuk ketiga jenis toko tersebut ditampilkan dalam tabel di bawah. 
Tabel 5. Perbandingan Jarak Rata-rata antara Toko dan konsumen (2)

\begin{tabular}{lrrr} 
& Toko 1 & \multicolumn{1}{c}{ Toko 4 } & \multicolumn{1}{c}{ Toko 5 } \\
\hline AVERAGE & 785 & 1155 & 1080 \\
STDV & 435 & 512 & 504 \\
\hline
\end{tabular}

Toko 4 dan Toko 5 memiliki daya tarik efektif yang lebih besar dari Toko 1, atau dapat dikatakan bahwa Toko yang menjajakan produk yang relatifhomogen akan memiliki daya tarik efektif yang relatif lebih besar lebih besar dibandingkan dengan toko yang menjajakan produk yang beragam. Hal tersebut ditunjukkan oleh besarnya angka jarak rata-rata dalam tabel di atas. Uji Hypothesis terhadap ragam produk yang ditawarkan adalah:

Ho (2) : Tidak terdapat perbedaan signifikan atas daya tarik toko terhadap konsumen karena perbedaan ragam (variasi) produk yang ditawarkan.

Pengujian hypothesis di atas dilakukan dengan menghitung $\mathrm{t}$ value yang kemudian disampaikan dalam Tabel 6. Angka t tabel untuk $\alpha=5 \%$, Ho diterima jika angka $\mathrm{t}$ terletak dalam rentang harga antara $-1,96<\mathrm{t}<1,96$. Hasil $\mathrm{t}$ hitung dalam tabel di bawah menunjukkan bahwa antara Toko 1 (mewakili produk yang tidak homogen) dan Toko 4 maupun Toko 5 (mewakili toko dengan produk yang relatif homogen), keduanya berada diluar rentang harga persyaratan $\mathrm{Ho}(2)$ diterima, sehingga $\mathrm{Ho}(2)$ ditolak. Hasil uji hypothesis ini mengatakan bahwa terdapat perbedaan yang signifikan atas daya tarik toko terhadap konsumen karena perbedan ragam (variasi) produk yang ditawarkan.

Tabel 6. Perhitungan t value (2)

\begin{tabular}{cccc}
\hline $\mathrm{t}$ value & Toko 1 & Toko 4 & Toko 5 \\
\hline Toko 1 & 0.0 & -4.3 & -3.4 \\
Toko 4 & 4.3 & 0.0 & -0.8 \\
Toko 5 & 3.4 & 0.8 & 0.0 \\
\hline
\end{tabular}

Kesimpulan dari analisis ini adalah semakin homogen produk yang ditawarkan oleh toko, maka semakin besar radius (jarak) pengaruhnya terhadap konsumen untuk ingin datang ke toko tersebut.

\section{PENUTUP}

Simpulan. Penelitian dengan pendekatan kuantitatif ini cukup dapat menjelaskan pengaruh ukuran toko dan keragaman produk terhadap daya tarik toko terhadap konsumen, meskipun demikian penelitian kuantitatif ini memiliki kelemahan dikarenakan dalam penelitian ini dilakukan dalam rentang waktu yang pendek dengan memilih 5 (lima) titik pengamatan dan 60 (enam puluh) sampel untuk tiap titik pengamatan. Analisis Toko4 dan Toko-5 yang menjajakan produk yang relatif seragam (homogen) ternyata memiliki perbedaan daya tarik yang ditunjukkan oleh perbedaan angka jarak efektif rata rata, hal ini karena jenis produk yang dijajakan berbeda yaitu kue dan buah, akan tetapi hal ini tidak signifikan karena thitung berada dalam rentang persyaratan $t$ tabel $(-1,96<t<1,96)$ agar 
Ho diterima dengan Ho: tidak ada perbedaan yang signifikan atas daya tarik toko terhadap perbedaan komoditas (produk) yang ditawarkan pada 2 toko yang homogen. Ternyata selain perbedaan ukuran, dan homogenitas produk barang (goods) juga macam produk barang (goods) turut mempengaruhi jarak efektifrata rata. Temuan perbedaan produk ini menarik untuk diteliti lebih lanjut dengan melibatkan produk seragam (homogen) lainnya seperti: toko alat tulis, toko elektronik, toko kain, dan lain-lain.

Secara umum dapat dikatakan bahwa toko berukuran kecil dapat bergabung dalam suatu kelompok (sentra perdagangan) untuk dapat meningkatkan daya tarik konsumen sehingga dapat menyaingi ukuran toko yang lebih besar. Toko yang berukuran kecil dapat pula lebih mengkhususkan kepada poduk yang lebih homogen untuk dapat meningkatkan daya tarik toko terhadap konsumen.

Saran. Penelitian kuantitatif dengan menggunakan bukti empirik yang lebih banyak akan sangat membantu untuk lebih meyakinkan reliability model Coulomb dalam mengukur jarak optimum (efektif) daya tarik Toko terhadap konsumen, sehingga dapat diperoleh besaran besaran kuantitatif yang dapat digunakan dalam menetapkan jarak optimum antar toko untuk menghindari atau mengurangi fenomena "kanibalisme konsumen".

\section{DAFTAR RUJUKAN}

Adri Poesoro, (2008) "Dampak Supermarket terhadap Keberadaan Pasar Tradisional di Daerah Perkotaan di Indonesia", Jurnal Bisnis \& Ekonomi Politik Vol 9 (2), INDEF, April, 2008, hal. 1-8.

Ahmad E Yustika, (2008) "Refleksi Kompetensi Hypermarket dalam Pasar Tradisional", Jurnal Bisnis \& Ekonomi Politik Vol 9 (2), INDEF, April, 2008, hal. 71-84

Asep Sujana, (2005) Paradigma Baru dalam Manajemen Ritel Modern, Cetakan 1, Graha Ilmu, Yogyakarta.

Dwinita Aryani, (2011) "Efek Pendapatan Pedagang Tradisional dari Ramainya Kemunculan Minimarket di Kota Malang", Jurnal Dinamika Manajemen - ISSN 2086-0668, Vol 2 (2), 2011, hal. 169-180.

Euis Soliha, (2008) “Analisis Industri Ritel di Indonesia”, Jurnal Bisnis \& Ekonomi (JBE) - ISSN: 1412-3126, September 2008, hal 128 - 142

Gilbert, David, (2003) Retail Marketing Management, $2^{\text {nd }}$ Ed, Prentice Hall.

Goldman Arieh, (2005) "Supermarket vs Tradisional Retail Stores: Diagnosing the Barrier to Supermarkets' Market Share Growth in an Etnic Minority Community", Journal of Retailing and Consumer Services 12 (2005), p. 273 -284

Griffiths, David J. (1998) Introduction to Electrodynamics ( $3^{\text {rd }}$ Ed.). Prentice Hall.

Lukas Setia Atmaja, (2009) Statistika untuk Bisnis dan Ekonomi, Penerbit Andi, Yogyakarta.

Nel Ariyanti, (2013) "Analisis Perbedaan Pasar Modern dan Pasar Tradisional Ditinjau dari Strategi Tata Letak (Lay Out) dan Kualitas Pelayanan untuk Meningkatkan Posisi Tawar Pasar Tradisional", Jurnal Manajemen \& Bisnis, Vol 13 (1), ISSN 1693 - 7619, April 2013, hal. 18-29

Peraturan Presiden No. 112 Tahun 2007 tentang Penataan dan Pembinaan Pasar Tradisional, Pusat Perbelanjaan dan Toko Modern. 
Rahmat, (2013) Statistika Penelitian, Pustaka Setia, Bandung.

Rina Indiastuti \& Aziz Y, (2008) "Analisis Keberlanjutan Pasar Tradisional dalam Iklim Persaingan Usaha yang Dinamis di Kota Bandung”, Jurnal Sosiohumaniora, Vol 10, (2), 2008, hal. 17-37

Salvatore, Dominick, (2006) Schaum's O utline M ikroekonomi, Erlangga, Jakarta. Sekaran, Uma, (2010) Research Method for Business $5^{\text {th }}$ Ed., John Wiley \& Sons.

Teller, Christoph \& Thomas Reutter, (2008) "The Evolving of Retail Attractiveness: What makes Retail Agglomeration Attractive when Customer Shop at Them?", Jurnal of Retailing and Consumer Services. Vol. 15, Issues 3, May 2008, p. 127 - 143 